University of Nebraska - Lincoln

DigitalCommons@University of Nebraska - Lincoln

\title{
The Effects of BleedArrest, Celox, and TraumaDex on Hemorrhage Control in a Porcine Model
}

\author{
Brian Gegel \\ Brooke Army Medical Center \\ James Burgert \\ Brooke Army Medical Center \\ Brian Cooley \\ US Army Graduate Program in Anesthesia Nursing \\ Jacob MacGregor \\ US Army Graduate Program in Anesthesia Nursing \\ Jules Myers \\ US Army Graduate Program in Anesthesia Nursing \\ See next page for additional authors
}

Follow this and additional works at: https://digitalcommons.unl.edu/usarmyresearch

Part of the Operations Research, Systems Engineering and Industrial Engineering Commons

\begin{abstract}
Gegel, Brian; Burgert, James; Cooley, Brian; MacGregor, Jacob; Myers, Jules; Calder, Sean; Luellen, Ralph; Loughren, Michael; and Johnson, Don, "The Effects of BleedArrest, Celox, and TraumaDex on Hemorrhage Control in a Porcine Model" (2010). US Army Research. 124.

https://digitalcommons.unl.edu/usarmyresearch/124
\end{abstract}

This Article is brought to you for free and open access by the U.S. Department of Defense at DigitalCommons@University of Nebraska - Lincoln. It has been accepted for inclusion in US Army Research by an authorized administrator of DigitalCommons@University of Nebraska - Lincoln. 


\section{Authors}

Brian Gegel, James Burgert, Brian Cooley, Jacob MacGregor, Jules Myers, Sean Calder, Ralph Luellen, Michael Loughren, and Don Johnson 


\title{
The Effects of BleedArrest, Celox, and TraumaDex on Hemorrhage Control in a Porcine Model
}

\author{
Brian Gegel, M.S.N., ${ }^{*}$ James Burgert, M.S.N.A.,† Brian Cooley, B.S.N.,\$ Jacob MacGregor, B.S.N.,\$ \\ Jules Myers, B.S.N. $\neq$ Sean Calder, B.S.N., $\neq$ Ralph Luellen, BSN, $\neq$ Michael Loughren, Ph.D.,§ \\ and Don Johnson, Ph.D. $\S^{\S}$ \\ *Assistant Program Director, Phase II Site, US Army Graduate Program in Anesthesia, Brooke Army Medical Center, Fort Sam, \\ Houston, Texas; $\dagger$ Adjunct Clinical Faculty, Brooke Army Medical Center, Fort Sam, Houston, Texas; $\ddagger$ Graduate Student, US Army \\ Graduate Program in Anesthesia Nursing, Fort Sam Houston, Texas; and §Faculty, US Army Graduate Program in Anesthesia Nursing, \\ Fort Sam Houston, Texas
}

Submitted for publication May 20, 2010

Background. Hemorrhage is the second leading cause of death in civilian trauma and the leading cause of preventable death in military trauma. The purpose of this study was to examine the effectiveness of three hemostatic agents: BleedArrest, TraumaDex, and Celox.

Materials and Methods. This was a prospective, experimental study using male Yorkshire swine. The pigs ( $n=5$ per group) were randomly assigned to one of the following: BleedArrest, TraumaDex, Celox, or control. To simulate a trauma injury, the investigators generated a complex groin injury with transection of the femoral artery and vein in all pigs. After $1 \mathrm{~min}$ of uncontrolled hemorrhage, one of the hemostatic agents was poured into the wound, followed by standard wound packing. The control group underwent the same procedures with the exception of the hemostatic agents. In all groups, 5 min of direct manual pressure was applied to the wound followed by a standard pressure dressing. After 30 min, dressings were removed, and the amount of bleeding was determined.

Results. There were significant differences between the BleedArrest $($ mean $=21.2, \mathrm{SD} \pm 36.6 \mathrm{~mL})$ TraumaDex $($ mean $=68, S D \pm 103.5 \mathrm{~mL})$ and Celox $(\operatorname{mean}=18.16, \mathrm{SD} \pm$ 41.6 mL) groups compared with Control group $($ mean $=$ $230, \mathrm{SD} \pm 154 \mathrm{~mL})(P<0.05)$. However, there were no statistically significant difference between BleedArrest, TraumaDex, and Celox groups $(P=0.478)$.

Conclusions. BleedArrest, Celox, and TraumaDex were statistically and clinically superior at controlling

\footnotetext{
1 To whom correspondence and reprint requests should be addressed at Department of the Army, Academy of Health Sciences, 3490 Forage Road, Fort Sam Houston, TX, 78234-6130. E-mail: Arthur.johnson@amedd.army.mil.
}

hemorrhage compared with the standard pressure dressing in the control group. Published by Elsevier Inc.

Key Words: hemorrhage; hemorrhage control; hemostatic agents.

\section{INTRODUCTION}

Uncontrolled hemorrhage is the second leading cause of death in civilian trauma [1] and the leading cause of preventable death in military trauma [1-9]. Historically, $20 \%$ of combat casualties were killed in action. Ninety percent of those deaths occurred prior to arrival at a field hospital with exsanguination as the leading cause of death [5]. Of the soldiers who died from exsanguination in Vietnam, $40 \%$ had bleeding that may have been controlled by a hemostatic agent [8].

If trauma victims survive the initial blood loss, they are prone to hypothermia, coagulopathy, acidosis, infection, and multiple organ failure. These complications result in an increase in mortality even after successful resuscitation [1, 9-11]. Avoiding this lethal cascade requires hemorrhage control prior to arrival at the hospital minimizing blood loss and allowing for earlier resuscitation [12-14, 15].

Several hemostatic agents have been investigated over the past decade with mixed and inconclusive results [15-17, 18-21, 22, 23, 24, 25, 26-28, 29, 30, 31, 32-34]. The purpose of this study was to examine the effectiveness of three hemostatic agents: BleedArrest, TraumaDex, and Celox. The research question guiding this study was as follows: Is there a statistically 
significant difference in the amount of bleeding among BleedArrest, TraumaDex, Celox, and the control group?

The mechanism of action of BleedArrest (Hemostasis LLC, St. Paul, MN) is based on the absorbance of plasma by amylopectin, a plant-based starch. The result is the concentration of platelets and coagulation factors at the site of injury supporting the formation of a robust clot. Similarly, TraumaDex (Medafor Corporation, Minneapolis, MN) is based on a plant-based starch, referred to as microporous polysaccharide hemospheres technology. The polysaccharides act as microscopic sponges that absorb plasma, concentrate platelets and coagulation factors, and form a gel-like matrix enhancing clot formation.

Celox (Medtrade Biopolymers, Crewe, UK, distributed in the United States by SAM Products, Portland, OR) uses chitosan, produced by the deacetylation of chitin, a polysaccharide derived from the exoskeleton of shrimp. Chitosan is positively charged and bonds readily to the negatively charged surfaces of red blood cells, forming an adhesive complex that works independently of clotting factors.

\section{MATERIALS AND METHODS}

This study was a prospective, between-subjects experimental design using a porcine model. The protocol was approved by the Institutional Animal Care and Use Committee (IACUC). The animals received care in accordance with the Animal Welfare Act and The Guide for the Care and Use of Laboratory Animals. Twenty male Yorkshire swine weighing between 70 and $89 \mathrm{~kg}$ were randomly assigned ( $n=5$ per group) to one of four groups: BleedArrest, TraumaDex, Celox, or the control group. The rationale for using swine of this size was that they represent the average weight of the US Army soldier [35]. The swine were observed for $3 \mathrm{~d}$ to ensure a good state of health, fed a standard diet, and were NPO after midnight the day of the experiment. This study was conducted in four phases: induction/stabilization, hemorrhage, hemostasis, and blood loss.

\section{Induction/Stabilization Phase}

The induction phase started with an intramuscular injection of ketamine $(20 \mathrm{mg} / \mathrm{kg})$ and atropine $(0.04 \mathrm{mg} / \mathrm{kg})$. Subjects were placed supine on a litter and transported to an operating room followed by inhaled isoflurane (4\% to 5\%). After placement of an endotracheal tube, a peripheral i.v. catheter was inserted and the isoflurane concentration was reduced to $1 \%$ to $2 \%$ for the remainder of the experiment. The swine were ventilated with a standard Narkomed anesthesia machine (Dräger, Telford, PA). Heart rate, electrocardiography, blood pressure, oxygen saturation, end-tidal carbon dioxide, and rectal temperatures were continuously monitored for the remainder of the experiment. A Thermal Industries of Florida (TIF) scale, model 9010A, (SPX Service Solutions, Owatonna, MN) was placed between the litter and operating room table. The TIF scale is an electronic scale that measures pressure applied in pounds per square inch and is precise within 0.5 ounces and accurate within $0.5 \%$. The scale was zeroed per manufacturer's instructions. While manual pressure was applied to the wound during the experiment, the scale was observed to ensure pressure was maintained at 25 pounds per square inch within \pm 0.5 ounces to ensure continuity from subject to subject.

The left carotid artery was cannulated with a $20 \mathrm{G}$ angio-catheter using a cut down technique. A central venous catheter was inserted using a modified Seldinger technique for fluid volume management and blood sampling. The catheters were attached to a hemodynamic monitoring system (Hewlett Packard, Palo Alto, CA) for continuous monitoring of the arterial blood pressures. All catheters were continuously flushed with $0.9 \%$ saline solution ( $5 \mathrm{~mL}$ per $\mathrm{h}$ ) to maintain patency. Following line placement, the NPO fluid deficit was corrected with $0.9 \%$ normal saline, per the Holliday-Segar formula. The investigators used an activated clotting time (ACT) test to screen all subjects for coagulopathy prior to procedures. The upper limit in this study for all subjects was an ACT less than $150 \mathrm{~s}$. One subject in the BleedArrest group was excluded and replaced because of a prolonged ACT 2.5 times greater than the upper limit. Subjects were further monitored for $30 \mathrm{~min}$ to ensure hemodynamic stability prior to intervention. Body temperature was monitored via a rectal probe and maintained at greater than $36^{\circ} \mathrm{C}$ using a forced air-warming blanket. A complex groin injury as described by Alam and colleagues was generated to simulate a penetrating injury [27]. The injury included dissection of the proximal thigh soft tissues including the skin, quadriceps, and adductor muscles to expose the femoral artery and vein just below the inguinal ligament. All swine were hemodynamically stable prior to intervention.

\section{Hemorrhage Phase}

Following the $30 \mathrm{~min}$ stabilization period, the exposed femoral artery and vein were transected with a scalpel blade. The swine were allowed to hemorrhage for $1 \mathrm{~min}$, simulating the response time of a battlefield health care provider. Blood was collected by gauze, absorbent pads underneath the animals, and in a suction canister by use of a suction tip catheter placed in the distal portion of the wound.

\section{Hemostasis Phase}

After 1 min of hemorrhage, proximal pressure was applied to the transected femoral vessels, and 4 in. $\times 4$ in. gauze was used to blot the blood from the wound per the hemostatic agent manufacturer's guidelines. At this time, the hemostatic agent was poured into the wound followed by standard wound packing with a layer of petroleum gauze and the roller gauze (Kerlix; Covidien, Mansfield, MA). The control group received proximal pressure and standard wound packing. Firm manual pressure of $25 \mathrm{lbs}$ per square inch was applied for 5 min to the injury site as measured by the TIF scale. After 5 min, all groups received a Coban (3M Inc. St. Paul, MN) wrapped pressure dressing left in place for $30 \mathrm{~min} ; 500 \mathrm{~mL}$ of $6 \%$ Hextend in lactated Ringer's solution (Hospira, Inc., Lake Forest, IL) i.v. was administered to all subjects in accordance with current battlefield resuscitation protocol recommended by the Committee on Tactical Combat Casualty Care.

\section{Blood Loss Phase}

After 35 min of pressure on the wound ( 5 min manual pressure plus 30 min with the pressure dressing), the standard pressure dressing was removed being careful to keep the clot intact. The rationale for using the petroleum gauze was that it allowed removal of the pressure dressing with minimal clot disruption. For the purposes of this study, hemostasis was defined as a clot formation with oozing of no more than $2 \%$ of the swine's total blood volume over a $5 \mathrm{~min}$ period $(\sim 100 \mathrm{~mL}$ in a $70 \mathrm{~kg}$ pig). Blood loss was measured over two time periods: the initial injury to intervention and post-intervention to the completion of the study. Blood loss was calculated by weighing the dressings, absorbent pads underneath the animals, and blood suctioned from the distal portion of the wound before and after transection of the femoral vessels.

\section{RESULTS AND DISCUSSION}

The minimum number of animals was used to obtain a statistically valid result. A large effect size was 
TABLE 1

Amount of Hemorrhage by Group after 35 Min

\begin{tabular}{|c|c|c|c|}
\hline Group & Range & $\begin{array}{l}\text { Mean and standard deviation of } \\
\text { hemorrhage for } 5 \text { min }\end{array}$ & Post hoc analyses \\
\hline BleedArrest & $0-58 \mathrm{~mL}$ & $21 \pm 36.6 \mathrm{~mL}$ & BleedArrest versus control $(P=0.01)^{*}$ \\
\hline TraumaDex & from 0 to $234 \mathrm{~mL}$ & $68 \pm 103.5 \mathrm{~mL}$ & Celox versus control $(P=0.01)^{*}$ \\
\hline Celox & 0 to $93 \mathrm{~mL}$ & $18.16 \pm 41.6 \mathrm{~mL}$ & TraumaDex versus control $(P=0.038)^{*}$ \\
\hline Control & 0 to $421 \mathrm{~mL}$ & $230 \pm 154 \mathrm{~mL}$ & $\begin{array}{l}\text { BleedArrest versus Celox versus } \\
\text { TraumaDex }(P=0.478)\end{array}$ \\
\hline
\end{tabular}

determined for this experiment based upon previous work by Alam and Pusateri [21, 27]. Using G-Power 3.00 , an effect size of 0.6 , a power of 0.80 , and an $\alpha$ of 0.05 , it was determined that a sample size of five swine per group was needed for this study. Investigators evaluated coagulation studies with all subjects. There were no statistically significant differences between the groups in reference to the amount of initial bleeding after 1 minute $(P=0.533)$ : BleedArrest group ranged from 615 to $730 \mathrm{~mL}($ mean $=671.4, \mathrm{SD} \pm 55.8 \mathrm{~mL})$; TraumaDex group ranged from 400 to $954 \mathrm{~mL}$ (mean = 739.6, $\mathrm{SD} \pm 208 \mathrm{~mL}$ ); Celox group ranged from 300 to $900 \mathrm{~mL}($ mean $=541.6, \mathrm{SD} \pm 243 \mathrm{~mL})$; and Control group ranged from 205 to $862 \mathrm{~mL}$ (mean $=554.2, \mathrm{SD} \pm$ $305 \mathrm{~mL}$ ). The body weights, core body temperatures, amount of blood volume, and the amount of the initial 1 min hemorrhage were analyzed using a multivariate ANOVA. There were no statistically significant differences between the groups $(P>0.05)$, indicating that the groups were equivalent on these parameters. Blood loss after $35 \mathrm{~min}$ of pressure on the wound (manual pressure and pressure dressing) was calculated for each group over a 5 min observation period following removal of dressings and exposure of the formed clot. The amount of bleeding BleedArrest group ranged from 0 to $58 \mathrm{~mL}($ mean $=21.2, \mathrm{SD} \pm 36.6 \mathrm{~mL})$; TraumaDex group ranged from 0 to $234 \mathrm{~mL}$ (mean $=68$, $\mathrm{SD} \pm$ $103.5 \mathrm{~mL}$ ); Celox group ranged from 0 to $93 \mathrm{~mL}$ ( $\mathrm{mean}=$ $18.16, \mathrm{SD} \pm 41.6 \mathrm{~mL}$ ); and Control group ranged from 0 to $421 \mathrm{~mL}($ mean $=230, \mathrm{SD} \pm 154 \mathrm{~mL})$. An ANOVA and a least significant difference (LSD) hoc test were used to analyze the data and indicated a significant difference between the groups $(P=0.025)$. There were statistically significant differences between BleedArrest and control $(P=0.01$; TraumaDex and control $(P=0.038)$; Celox and control $(P=0.01)$. However, there were no statistically significant differences between BleedArrest, TraumaDex, and Celox groups $(P=$ 0.478). See Table 1 for a summary of the results.

The US Army's goal is that each soldier will carry a hemostatic agent, but research needs to be conducted to determine the most efficacious and cost effective agent. In addition, many civilian disaster teams and first responders are exploring the potential for using hemostatic agents before arrival to the hospital. Pusateri outlined the ideal qualities of hemostatic agents for civilian and military use. These include (1) being able to rapidly stop large vessel arterial and venous bleeding within 2 min of application when applied to an actively bleeding wound through a pool of blood; (2) no requirement for mixing or pre-application preparation; (3) simplicity of application by wounded victim, buddy, or medic; (4) light weight and durable; (5) long shelf life in extreme environments; (6) safe to use with no risk of injury to tissues or transmission of infection; and (7) inexpensive [36]. This study compared BleedArrest, Celox, and TraumaDex against a standard pressure dressing, the control, in a porcine model of lethal femoral vascular injury. A complex groin injury was generated simulating a penetrating injury, common in combat, in an anatomical area not protected by conventional body armor or amenable to use of a tourniquet. The hemostatic agents BleedArrest, TraumaDex, and Celox were all able to rapidly control arterial and venous bleeding. This fulfilled the first of Pusateri's requirements. Celox performed clinically superior to BleedArrest and TraumaDex, and all three were statistically and clinically superior at controlling hemorrhage compared with the standard pressure dressing control group. The hemostatic agents in this study were easy to apply and did not require any pre-mixing. Celox is packaged as $35 \mathrm{~g}$ of loose granules in a waterproof pouch. It was easy to open and pour into the wound. In contrast, TraumaDex comes packaged in a plastic tipped applicator containing $5 \mathrm{~g}$ of fine powder. Investigators noted, during model development, contact of the applicator tip with blood in the wound caused clotting within the applicator itself. Therefore, investigators removed the TraumaDex powder from the applicator, measured it into a weighed envelope, and poured it into the wound in the same manner as Celox. BleedArrest comes packaged in a 250 g easy to open envelope. The investigators used enough of the hemostatic agent to completely fill the groin injury cavity. The mean weights of the hemostatic agents were as follows: BleedArrest $24.3 \mathrm{~g}$, TraumaDex $24.8 \mathrm{~g}$, and Celox $23.8 \mathrm{~g}$. Standard packaging of the agents in small waterproof packets allows soldiers and combat medics to easily carry these 
agents in pockets, backpacks, or medic bags. These agents could also be easily used by physicians, nurses, and ordinary citizens in providing care in the civilian arena. Because of the nature of the products, exposure to heat or cold does not appear to be a factor in determining shelf life. BleedArrest has a shelf life of $3 \mathrm{y}$; Celox has a shelf life of $2 \mathrm{y}$; and TraumaDex for $3 \mathrm{y}$. All of the agents are approved by the FDA. In this study, investigators noted that none of the agents produced an exothermic reaction when applied to the wound, and there were no obvious signs of tissue damage. There were concerns and reports of thermal injury to human tissue with some first generation mineral-based hemostatic agents [37]. Secondary to the mechanisms of action and the sterilization of these products, none of the agents tested carries the risk of infection per the manufacturers. The three hemostatic agents are relatively inexpensive, all costing less than $\$ 30.00$ for a single application and less when the agents are bought in bulk. Investigators used approximately five applications of TraumaDex compared with one of Celox and BleedArrest applications to ensure equivalent weights of the agents.

\section{CONCLUSION}

BleedArrest, Celox, and TraumaDex were statistically and clinically superior at controlling hemorrhage compared with the standard pressure dressing in the control group. All of these hemostatic agents are FDA approved, simple to use, light weight, have a long-shelf life, demonstrate no known risk of tissue injury, and are relatively inexpensive. Based on this study and the requirements outlined by Pusateri, these hemostatic agents are effective for use in civilian and military trauma management.

\section{REFERENCES}

1. Sauaia A, Moore FA, Moore EE, et al. Epidemiology of trauma deaths: A reassessment. J Trauma 1995;38:185.

2. Champion HR, Bellamy RF, Roberts CP, Leppaniemi A. A profile of combat injury. J Trauma 2003;54(5 Suppl):S13.

3. Asensio JA, Petrone P, O'Shanahan G, et al. Managing exsanguination: What we know about damage control/bailout is not enough. Proc (Bayl Univ Med Cent) 2003;16:294.

4. Asensio JA, Petrone P, Roldan G, et al. Analysis of 185 iliac vessel injuries: Risk factors and predictors of outcome. Arch Surg 2003;138:1187. discussion 1193.

5. Bellamy RF. The causes of death in conventional land warfare: Implications for combat casualty care research. Mil Med 1984;149:55.

6. Gofrit ON, Leibovici D, Shapira SC, et al. The trimodal death distribution of trauma victims: Military experience from the Lebanon War. Mil Med 1997;162:24.

7. Hoyt DB, Bulger EM, Knudson MM, et al. Death in the operating room: An analysis of a multi-center experience. J Trauma 1994;37:426.

8. Mabry RL, Holcomb JB, Baker AM, et al. United States Army Rangers in Somalia: An analysis of combat casualties on an urban battlefield. J Trauma 2000;49:515. discussion 528.

9. Sauaia A, Moore FA, Moore EE, et al. Early predictors of postinjury multiple organ failure. Arch Surg 1994;129:39.
10. Cosgriff N, Moore EE, Sauaia A, et al. Predicting lifethreatening coagulopathy in the massively transfused trauma patient: Hypothermia and acidoses revisited. J Trauma 1997; 42:857. discussion 861 .

11. Heckbert SR, Vedder NB, Hoffman W, et al. Outcome after hemorrhagic shock in trauma patients. J Trauma 1998;45:545.

12. Santry HP, Alam HB. Fluid resuscitation: Past, present, and the future. Shock 2010;33:229.

13. Scope A, Farkash U, Lynn M, et al. Mortality epidemiology in lowintensity warfare: Israel Defense Forces' experience. Injury 2001;32:1.

14. Zajtchuk R, Sullivan GR. Battlefield trauma care: Focus on advanced technology. Mil Med 1995;160:1.

15. Ward KR, Tiba MH, Holbert WH, et al. Comparison of a new hemostatic agent to current combat hemostatic agents in a swine model of lethal extremity arterial hemorrhage. J Trauma 2007; 63:276. discussion 283.

16. Pusateri AE, Delgado AV, Dick EJ Jr, et al. Application of a granular mineral-based hemostatic agent (QuikClot) to reduce blood loss after grade V liver injury in swine. J Trauma 2004;57:555. discussion 562.

17. Jewelewicz DD, Cohn SM, Crookes BA, et al. Modified rapid deployment hemostat bandage reduces blood loss and mortality in coagulopathic pigs with severe liver injury. J Trauma 2003; 55:275. discussion 280.

18. Bishoff JT, Cornum RL, Perahia B, et al. Laparoscopic heminephrectomy using a new fibrin sealant powder. Urology 2003;62:1139.

19. Pusateri AE, Modrow HE, Harris RA, et al. Advanced hemostatic dressing development program: Animal model selection criteria and results of a study of nine hemostatic dressings in a model of severe large venous hemorrhage and hepatic injury in swine. J Trauma 2003;55:518.

20. Sondeen JL, Pusateri AE, Coppes VG, et al. Comparison of 10 different hemostatic dressings in an aortic injury. J Trauma 2003;54:280.

21. Pusateri AE, McCarthy SJ, Gregory KW, et al. Effect of a chitosan-based hemostatic dressing on blood loss and survival in a model of severe venous hemorrhage and hepatic injury in swine. J Trauma 2003;54:177.

22. King DR, Cohn SM, Proctor KG. Modified rapid deployment hemostat bandage terminates bleeding in coagulopathic patients with severe visceral injuries. J Trauma 2004;57:756.

23. Kheirabadi BS, Acheson EM, Deguzman R, et al. Hemostatic efficacy of two advanced dressings in an aortic hemorrhage model in swine. J Trauma 2005;59:25. discussion 34.

24. Rothwell SW, Reid TJ, Dorsey J, et al. A salmon thrombin-fibrin bandage controls arterial bleeding in a swine aortotomy model. J Trauma 2005;59:143.

25. Jackson MR, Friedman SA, Carter AJ, et al. Hemostatic efficacy of a fibrin sealant-based topical agent in a femoral artery injury model: A randomized, blinded, placebo-controlled study. J Vasc Surg 1997;26:274.

26. Alam HB, Uy GB, Miller D, et al. Comparative analysis of hemostatic agents in a swine model of lethal groin injury. J Trauma 2003;54:1077.

27. Alam HB, Chen Z, Jaskille A, et al. Application of a zeolite hemostatic agent achieves $100 \%$ survival in a lethal model of complex groin injury in swine. J Trauma 2004;56:974.

28. Acheson EM, Kheirabadi BS, Deguzman R, et al. Comparison of hemorrhage control agents applied to lethal extremity arterial hemorrhages in swine. J Trauma 2005;59:865. discussion 874 .

29. Arnaud F, Tomori T, Saito R, et al. Comparative efficacy of granular and bagged formulations of the hemostatic agent QuikClot. J Trauma 2007;63:775.

30. Ahuja N, Ostomel TA, Rhee P, et al. Testing of modified zeolite hemostatic dressings in a large animal model of lethal groin injury. J Trauma 2006;61:1312.

31. Kozen BG, Kircher SJ, Henao J, et al. An alternative hemostatic dressing: Comparison of CELOX, HemCon, and QuikClot. Acad Emerg Med 2008;15:74. 
32. Wedmore I, McManus JG, Pusateri AE, et al. A special report on the chitosan-based hemostatic dressing: Experience in current combat operations. J Trauma 2006;60:655.

33. Kheirabadi BS, Scherer MR, Estep JS, et al. Determination of efficacy of new hemostatic dressings in a model of extremity arterial hemorrhage in swine. J Trauma 2009;67:450. discussion 459.

34. Kheirabadi BS, Edens JW, Terrazas IB, et al. Comparison of new hemostatic granules/powders with currently deployed hemo- static products in a lethal model of extremity arterial hemorrhage in swine. J Trauma 2009;66:316. discussion 327.

35. Kues AB. The physical stature and bmi values of US Army personnel in 1988. J Biosoc Sci 2008;40:481.

36. Pusateri AE, Holcomb JB, Kheirabadi BS, et al. Making sense of the preclinical literature on advanced hemostatic products. J Trauma 2006;60:674.

37. Alam HB, Burris D, DaCorta JA, et al. Hemorrhage control in the battlefield: Role of new hemostatic agents. Mil Med 2005;170:63. 